\title{
Boron removal from aqueous solution by direct contact membrane distillation
}

\author{
Deyin Hou, Jun Wang*, Xiangcheng Sun, Zhaokun Luan, Changwei Zhao, Xiaojing Ren \\ State Key Laboratory of Environmental Aquatic Chemistry, Research Center for Eco-Environmental Sciences, Chinese Academy of Sciences, P.O. Box 2871, Beijing 100085, China
}

\section{A R T I C L E I N F O}

\section{Article history:}

Received 21 July 2009

Received in revised form

16 December 2009

Accepted 17 December 2009

Available online 23 December 2009

\section{Keywords:}

Membrane distillation

Boron removal

Rejection

Permeate flux

\begin{abstract}
A B S T R A C T
The removal of boron from aqueous solution by direct contact membrane distillation (DCMD) was studied with self-prepared polyvinylidene fluoride (PVDF) hollow fiber membranes in the present work. The effect of $\mathrm{pH}$, boron concentration, temperature and salt concentration of the feed solution on the boron rejection was investigated. The experimental results indicated that boron rejection was less dependent on the feed $\mathrm{pH}$ and salt concentration. DCMD process had high boron removal efficiency $(>99.8 \%)$ and the permeate boron was below the maximum permissible level even at feed concentration as high as $750 \mathrm{mg} / \mathrm{L}$. Although the permeate flux was enhanced exponentially with the feed temperature increasing, the influence of feed temperature on the boron rejection could be neglected. Finally, the natural groundwater sample containing $12.7 \mathrm{mg} / \mathrm{L}$ of boron was treated by DCMD process. The permeate boron kept below $20 \mu \mathrm{g} / \mathrm{L}$ whether the feed was acidified or not, but pre-acidification was helpful to maintain the permeate flux stability. All the experimental results indicated that DCMD could be efficiently used for boron removal from aqueous solution.
\end{abstract}

(c) 2009 Elsevier B.V. All rights reserved.

\section{Introduction}

Boron element is generally found in natural water as boric acid and borate salts depending on the $\mathrm{pH}$ of the water [1]. The concentration of boron in groundwater depends on the surrounding geological characteristics [2], its presence in surface water occurs frequently as a consequence of the discharge of treated sewage effluents and it is also commonly present in the oceans.

Boron is one of the most important micro-nutrients for plants, and is essential for plant growth. However, boron is beneficial to plants only in small quantities, as excessive amounts are injurious and even lethal. Irrigating water with more than $1.0 \mathrm{mg} / \mathrm{L}$ of boron is harmful to most plants [3]. Long-term exposure to water with increased boron content can result in malfunctioning of cardiovascular, nervous, alimentary, and sexual systems of humans and animals. Blood composition changes, physical and intellectual progress of children decelerates and risk of the pathological births increases [4-7]. A standard for boron in drinking water at $0.5 \mathrm{mg} / \mathrm{L}$ was adopted in China recently, which was in accordance with the guidance value of boron in drinking water recommended by WHO [8]. In European Union (EU), the standard for boron in drinking water was $1.0 \mathrm{mg} / \mathrm{L}$.

The existent accepted methods for the boron removal from water are mainly adsorption, ion exchange, and membrane process.

\footnotetext{
* Corresponding author. Tel.: +86 10 62849198; fax: +861062849198.

E-mail address: junwang@rcees.ac.cn (J. Wang).
}

Adsorption was considered as a more useful and economical technique for boron removal [9]. Activated carbon [10], oxides [11-13], and other low-cost materials such as fly ash [14], red mud [15] and clays [16] have been used as boron adsorbents. Adsorption process can remove boron to the safe concentration and the treatment is cost-effective. However, the removal of boron is greatly affected by temperature, $\mathrm{pH}$ and mass of adsorbent. Besides, this method requires a regeneration process after the adsorbents being exhausted, which may decrease the capacity of adsorbents and produce secondary pollution.

Ion-exchange process in which $N$-methyl glucamine type resins such as Amberlite XE 243, Amberlite JRN-78, Amberlite IRA743, Diaion CRB01, Diaion CRB02, Wofatit MK51 and Purolite S108 have been used is the most extensively studied and reported in the literature [17-25]. As the most efficient method, ion-exchange process can even remove boron to levels of $<50 \mu \mathrm{g} / \mathrm{L}$, far below the required limits [26]. Although the resin performance is not affected by temperature or $\mathrm{pH}$ value variations of the water to be treated, the process is usually not feasible under high background salinity [27]. Besides, the high cost of resins regeneration also limits the application fields of this method.

Reverse osmosis (RO) and electrodialysis (ED) are two common membrane processes used for boron removal [28-34]. Due to the chemistry of boron, the boron is in the form of boric acid at natural $\mathrm{pH}$ and ED is only capable of removing about $42-75 \%$ of boron, in the case of RO treatment, this is 30-40\% [31]. The low rejection of boric acid can be mainly attributed to its ability to diffuse through the membranes in a non-ionic form in the way similar to carboxylic acids or water [34]. Some investigation results showed that boric 
acid might be efficiently rejected only in its ionic form at a relatively high feed water $\mathrm{pH}[32,33]$.

Membrane distillation (MD) is a thermally driven process that involves transport of water vapor through a porous hydrophobic membrane [35]. During the MD process of solutions with non-volatile solutes, only water vapor can transfer through the membrane. It may be used as a substitute for conventional separation processes such as multistage vacuum evaporation, reverse osmosis, and distillation [36]. Compared with those processes, the advantages of MD are as follows: (1) lower operating temperature and vapor space required than conventional distillation, (2) lower operating pressure than $\mathrm{RO}$, (3) 100\% (theoretical) rejection of non-volatile solute, (4) unlimited by high osmotic pressure and (5) lower energy consumption than multistage vacuum evaporation $[37,38]$. Up to the present, MD has been applied for water desalination [39], wastewater reuse [40], juice concentration processing [41] and other industrial areas [42-44]. However, as far as we know, removal of boron from aqueous solution by MD has not been rigorously investigated.

Direct contact membrane distillation (DCMD) is the best known configuration of MD, in which the feed and the distillate are directly separated by the hydrophobic membrane. In the present study, DCMD experiments were carried out for boron removal.

\section{Materials and methods}

\subsection{Reagents}

All the chemicals used in the experiments were of analytical reagent grade. $\mathrm{H}_{3} \mathrm{BO}_{3}$ was obtained from E. Merck (Darmstadt, Germany). $\mathrm{NaCl}, \mathrm{CaCl}_{2}, \mathrm{Na}_{2} \mathrm{SO}_{4}, \mathrm{NaOH}$ and hydrochloric acid were supplied by Beijing Chemical works (China). Boron solution was prepared by dissolving $\mathrm{H}_{3} \mathrm{BO}_{3}$ with deionized water. And the other solutions were also prepared with deionized water.

\subsection{Membrane and membrane module}

The self-made membrane was spun from PVDF/N,N-dimethylacetamide (DMAc)/LiCl/ethylene glycol (EG) (12/80/5/3 wt\%) dope by phase inversion process. The mixture of $\mathrm{LiCl}$ and $\mathrm{EG}$ was used as non-solvent additive and DMAc was solvent. The characteristics of the PVDF hollow fiber membrane are given in Table 1 . The dry PVDF hollow fibers in the number of 50 pieces were assembled into a polyester tube (diameter $\left.(\mathrm{mm}) d_{\text {in }} / d_{\text {out }}=15 / 20\right)$ with two UPVC T-tubes and two ends of the bundle of fibers were sealed with solidified epoxy resin to form a membrane module. The total membrane length and the effective membrane length were 240 and $100 \mathrm{~mm}$, respectively. The total efficient area of the module was about $140 \mathrm{~cm}^{2}$ calculated based on the internal diameter of hollow fiber membrane.
Table 1

Characteristics of the membrane module.

\begin{tabular}{ll}
\hline Membrane material & Polyvinylidene fluoride \\
Housing material & Polyester \\
Inner diameter of the shell $(\mathrm{mm})$ & 15 \\
Inner diameter of the hollow fibers $(\mathrm{mm})$ & 0.90 \\
Thickness of the membrane wall $(\mathrm{mm})$ & 0.15 \\
Mean pore diameter $(\mu \mathrm{m})$ & 0.25 \\
Porosity $(\%)$ & 79.50 \\
Liquid entry pressure of water $(\mathrm{kPa})$ & 180 \\
Number of hollow fibers & 50 \\
Module packing density $(\%)$ & 32 \\
Effective membrane length $(\mathrm{mm})$ & 100 \\
Effective permeate area $\left(\mathrm{cm}^{2}\right)$ & 140 \\
\hline
\end{tabular}

\subsection{Apparatus}

Experiments were carried out with the apparatus shown in Fig. 1. The feed solution, $2.0 \mathrm{~L}$ in volume, was heated and maintained at the required temperature flowing through the lumen side of the fibers. The permeate flowed through the shell side and its temperature was held constant by a cooling coil. The feed and the permeate flowed concurrently from the bottom to the upper part of the module with the help of two magnetic pumps. The temperature of both fluids was monitored at the inlet and outlet of the membrane module using four thermometers. The permeate flux was calculated by the following equation:

$J=\frac{\Delta W}{A \Delta t}$

where $J$ is the permeate flux $\left(\mathrm{kg} / \mathrm{m}^{2} \mathrm{~h}\right), \Delta W$ is the quantity of permeate $(\mathrm{kg}), A$ is the effective permeate area of the hollow fiber module $\left(\mathrm{m}^{2}\right)$ and $\Delta t$ is the sampling time $(\mathrm{h})$.

\subsection{Boron removal experiments}

Boron removal experiments were carried out with hot boron acid aqueous solutions as the feed. The feed flow rate $\left(V_{f}\right)$ and the permeate flow rate $\left(V_{p}\right)$ were fixed at $60 \mathrm{~L} / \mathrm{h}$ and $65 \mathrm{~L} / \mathrm{h}$, respectively. During the DCMD process, the experiment with different feed was conducted for $10 \mathrm{~h}$ and the obtained permeate was reflowed to the feed reservoir every one hour to keep the feed concentration constant. Feed was replaced with fresh solution every $10 \mathrm{~h}$ and then the permeate sample was taken from the permeate reservoir for further analysis. The boron rejection efficiency $R$ was calculated according to the following equation:

$R(\%)=\frac{C_{f}-C_{p}}{C_{f}} \times 100 \%$

where $C_{f}$ is the feed boron concentration and $C_{p}$ is the permeate boron concentration. The parameters chosen in DCMD experiments carried out with cold permeate temperature $\left(T_{p}\right)$ at constant $20^{\circ} \mathrm{C}$

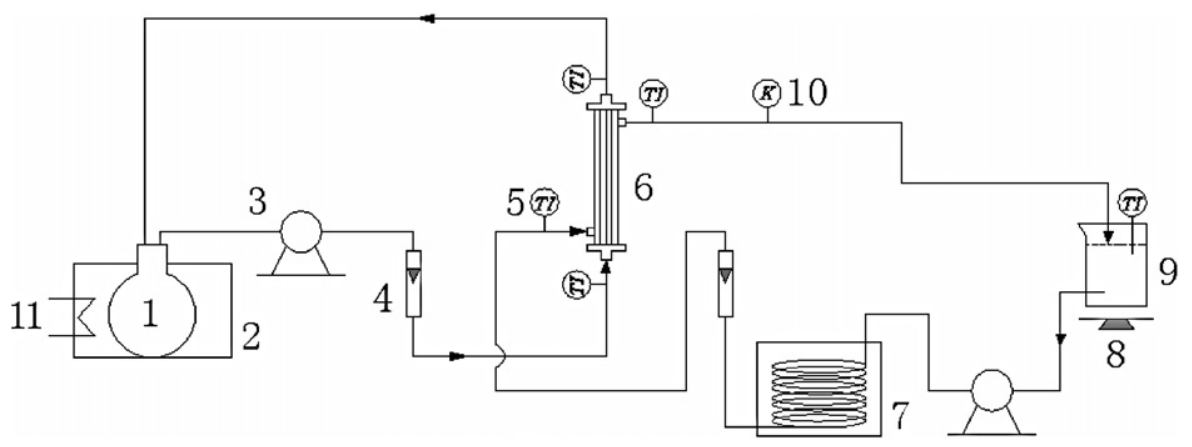

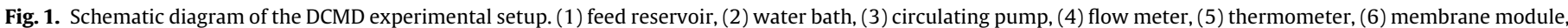
(7) cooling coil, (8) balance, (9) permeate reservoir, (10) conductivity monitor, and (11) heater. 
Table 2

Experimental parameters.

\begin{tabular}{ll}
\hline Parameters & Range \\
\hline $\mathrm{pH}$ & $3.0,5.0,7.0,9.0$ and 11.0 \\
Feed temperature $\left({ }^{\circ} \mathrm{C}\right)$ & $30,40,50,60,70$ and 80 \\
Boron concentration $(\mathrm{mg} / \mathrm{L})$ & $5,10,15,50,100,150,250,500,750,1000$, \\
& 1250 and 1500 \\
Feed salt concentration $(\mathrm{mg} / \mathrm{L})$ & $0,500,1000,2000,3000,4000$ and 5000 \\
\hline
\end{tabular}

were feed boron concentration, feed temperature $\left(T_{f}\right)$, pH and feed salt concentration, whose ranges are given in Table 2 . It must be noted that the liquid entry pressure of water (LEPw) of the membrane was $180 \mathrm{kPa}$ and much higher than water vapor pressure at temperature range of $30-80^{\circ} \mathrm{C}$, which ensured that the feed could not penetrate through the membrane directly and kept the DCMD system operating well.

\subsection{Natural groundwater application}

The application of DCMD on the natural groundwater was performed with the inlet temperatures of hot feed and cold permeate at constant $50^{\circ} \mathrm{C}$ and $20^{\circ} \mathrm{C}$, respectively. The feed flow rate was $60 \mathrm{~L} / \mathrm{h}$, while the permeate side being $65 \mathrm{~L} / \mathrm{h}$. The natural groundwater was taken from the northeastern region of Dandong (Liaoning Province, China). The chemical composition of the untreated natural groundwater was determined by three times analyses and the results are shown in Table 3.

\subsection{Analysis methods and instruments}

The concentration of boron in the permeate sample was determined by three times analyses using ICP-MS (7500a, Agilent, USA). The detection limit for boron was about $0.02 \mu \mathrm{g} / \mathrm{L}$ and the precision was about $<2.7 \%$ RSD with comparable levels of accuracy. Linearity for boron was observed in the concentration range of $1-100 \mu \mathrm{g} / \mathrm{L}$ and the coefficient of regression $\left(R^{2}\right)$ was 0.9996 . The permeate conductivity was measured using an electric conductivity monitor (CM-230A, Shijiazhuang Create Instrumentation Technologies, China).

The concentration of boron and cations in the natural groundwater were determined by ICP-AES (Optima 2000DV, PerkinElmer, USA). The wavelength utilized for boron determination was $249.772 \mathrm{~nm}$. Linearity for boron was observed in the concentration range of $1-100 \mathrm{mg} / \mathrm{L}$ and the coefficient of regression $\left(R^{2}\right)$ was 0.9998 . The detection limit for boron was about $0.05 \mathrm{mg} / \mathrm{L}$ and the precision was about $<3.0 \% \mathrm{RSD}$. Anions such as $\mathrm{F}^{-}, \mathrm{Cl}^{-}$ and $\mathrm{SO}_{4}{ }^{2-}$ in the natural groundwater were determined by the ion chromatography (861, Metrohm, Switzerland). Alkalinity, carbonate and bicarbonate were measured using an alkalinity titration, the conductivity of the feed was determined by using the conductivity meter (CO150, HACH, USA).

Both the fresh and the used membrane samples were frozen in liquid nitrogen, fractured to obtain fragments, sputtered with gold and then examined with a Hithche S-3000 scanning electron microscope (SEM) (Hitachi Ltd., Japan). Elemental analysis of the

Table 3

Chemical composition of the untreated natural groundwater sample ( $\mathrm{pH}=7.7$ ).

\begin{tabular}{llll}
\hline Ionic species & Value $(\mathrm{mg} / \mathrm{L})$ & Ionic species & Value $(\mathrm{mg} / \mathrm{L})$ \\
\hline $\mathrm{K}$ & $65.1 \pm 1.5$ & $\mathrm{~B}$ & $12.7 \pm 0.3$ \\
$\mathrm{Ca}$ & $214.3 \pm 3.8$ & $\mathrm{~F}^{-}$ & $2.1 \pm 0.4$ \\
$\mathrm{Na}$ & $1035.9 \pm 15.7$ & $\mathrm{Cl}^{-}$ & $2120.1 \pm 50.4$ \\
$\mathrm{Mg}$ & $208.1 \pm 2.1$ & $\mathrm{SO}_{4}{ }^{2-}$ & $511.7 \pm 10.8$ \\
$\mathrm{Fe}$ & Not detected & $\mathrm{HCO}_{3}{ }^{-}$ & $259.8 \pm 4.0$ \\
$\mathrm{Al}$ & Not detected & $\mathrm{CO}_{3}{ }^{2-}$ & Not detected \\
\hline
\end{tabular}

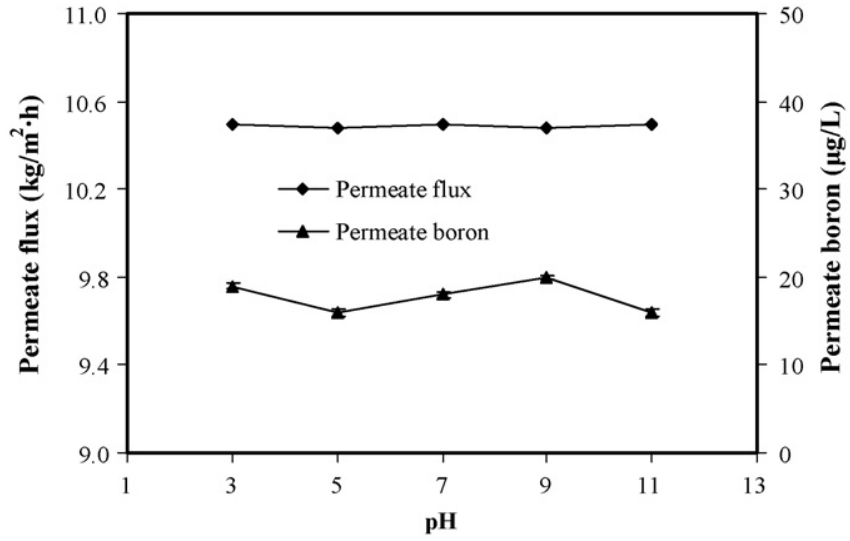

Fig. 2. Variation of permeate flux and permeate boron concentration as a function of the feed solution $\mathrm{pH}\left(V_{f}=60 \mathrm{~L} / \mathrm{h}, V_{p}=65 \mathrm{~L} / \mathrm{h}, T_{f}=50^{\circ} \mathrm{C}, T_{p}=20^{\circ} \mathrm{C}, C_{f}=15 \mathrm{mg} / \mathrm{L}\right)$.

scaled membranes was accomplished using energy dispersive Xray spectroscopy (EDS) analysis system.

\section{Results and discussions}

\subsection{Effect of $p H$}

To evaluate the effect of feed $\mathrm{pH}$ on the performance of DCMD process, a series of experiments were carried out with the hot feed at $50^{\circ} \mathrm{C}$, using aqueous solution containing boron of $15 \mathrm{mg} / \mathrm{L}$ as feed.

The dependence of the permeate flux and boron rejection on the feed $\mathrm{pH}$ is presented in Fig. 2. It can be found that the feed $\mathrm{pH}$ had no significant influence on the permeate flux and boron rejection. The permeate flux stabilized at about $10.5 \mathrm{~kg} / \mathrm{m}^{2} \mathrm{~h}$ during the whole process. In the feed $\mathrm{pH}$ range of 3.0-11.0, the permeate boron concentration was less than $20 \pm 0.25 \mu \mathrm{g} / \mathrm{L}$ and all the boron rejection could be over $99.8 \%$. Besides, the permeate conductivity kept below $2.0 \mu \mathrm{S} / \mathrm{cm}$, which was not illustrated in the figure.

As far as we know, it is impossible to get so high boron removal efficiency by RO membrane process, especially at natural $\mathrm{pH}(6.5-8.5)$ or under acid conditions. For RO membrane process, the high boron rejection is only obtained at $\mathrm{pH}>11.0$ because of the dissociation of boric acid. Being different from RO membrane process, MD uses the temperature gradient created on membrane surfaces as its driving force, which is less dependent on the feed $\mathrm{pH}$. For these reasons, the higher boron rejection can be obtained through the DCMD process whether the feed is alkali or acid.

\subsection{Effect of feed concentration}

The effect of feed concentration on the performance of DCMD process was investigated at natural $\mathrm{pH}$ without acid or alkali addition. The feed temperature was fixed at $50{ }^{\circ} \mathrm{C}$ and the feed boron concentration was in the range of $5-1500 \mathrm{mg} / \mathrm{L}$.

The permeate boron as a function of increasing feed boron concentration is shown in Fig. 3. It can be found that all the boron rejection efficiency could be over $99.8 \%$. The permeate boron concentration kept below the maximum permissible level even at feed boron concentration as high as $750 \mathrm{mg} / \mathrm{L}$. When the concentration of feed boron became $1250 \mathrm{mg} / \mathrm{L}$ and $1500 \mathrm{mg} / \mathrm{L}$, although the boron rejection efficiency could reach as high as $99.95 \%$, the permeate boron concentration increased to $0.63 \pm 0.01 \mathrm{mg} / \mathrm{L}$ and $0.71 \pm 0.02 \mathrm{mg} / \mathrm{L}$, respectively. This result can be attributed to partial wetting phenomenon because of a small amount large pores existed on the membrane surface. With the feed concentration increasing, both the feed viscosity and the boundary layer thick- 


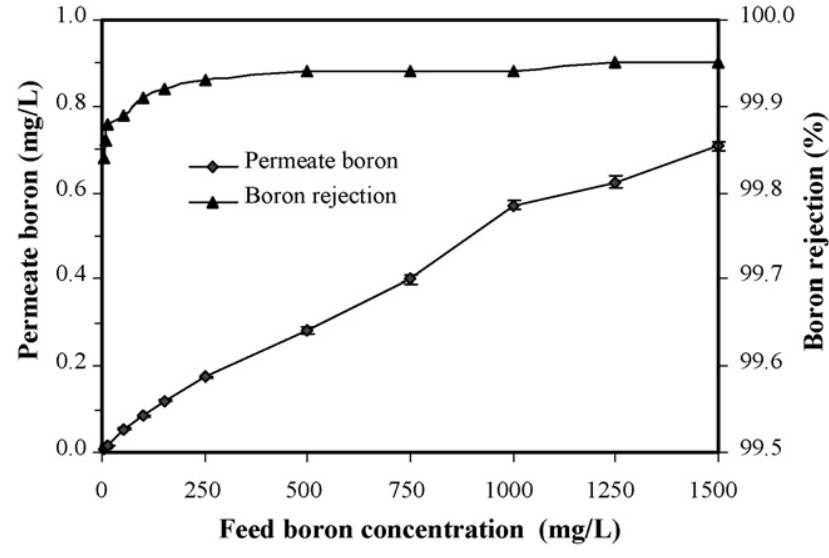

Fig. 3. Variation of permeate boron as a function of the feed boron concentration $\left(V_{f}=60 \mathrm{~L} / \mathrm{h}, V_{p}=65 \mathrm{~L} / \mathrm{h}, T_{f}=50^{\circ} \mathrm{C}, T_{p}=20^{\circ} \mathrm{C}\right.$, at natural pH 6.5-8.5).

ness increased, which would aggravate the membrane wetting. Therefore, the permeate boron concentration increased. It is an efficient method to optimize the hydrophobic membrane structure to ensure the permeate quality can meet the WHO recommendation limit. Besides, the RO/MD integrated membrane process could also be a recommendable method. The feed with high concentration boron was primarily treated by RO and then the RO permeate was treated by MD.

During the whole process, with the feed concentration increasing, the permeate flux stabilized at about $10.5 \mathrm{~kg} / \mathrm{m}^{2} \mathrm{~h}$, which meant that the feed concentration had no significant influence on permeate flux.

\subsection{Effect of feed temperature}

The influence of the feed temperature on permeate flux is shown in Fig. 4. It can be found that the feed temperature had a remarkable influence on permeate flux. With the feed temperature increasing, the permeate flux was enhanced exponentially. This trend could be explained by the Antoine equation [45] which predicted an exponential relationship between the vapor pressure difference and temperature. Besides, both the feed viscosity and the boundary layer thickness declined with the temperature increasing, which was favorable to enhance mass transfer coefficient.

From Fig. 5, it can be found that the effect of feed temperature on boron rejection could be neglected. The permeate boron concen-

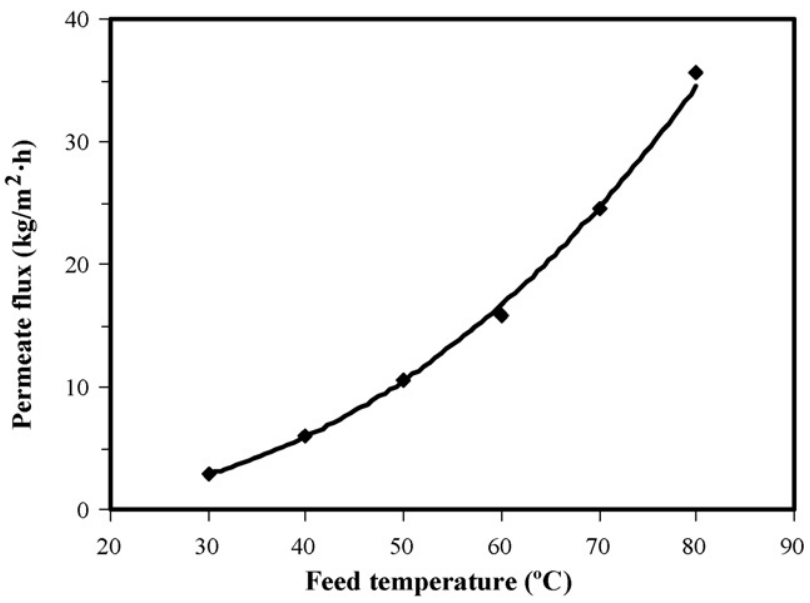

Fig. 4. Variation of permeate flux as a function of the feed temperature $\left(V_{f}=60 \mathrm{~L} / \mathrm{h}\right.$, $V_{p}=65 \mathrm{~L} / \mathrm{h}, T_{p}=20^{\circ} \mathrm{C}, C_{f}=15 \mathrm{mg} / \mathrm{L}$, at natural $\left.\mathrm{pH} 6.5-8.5\right)$.

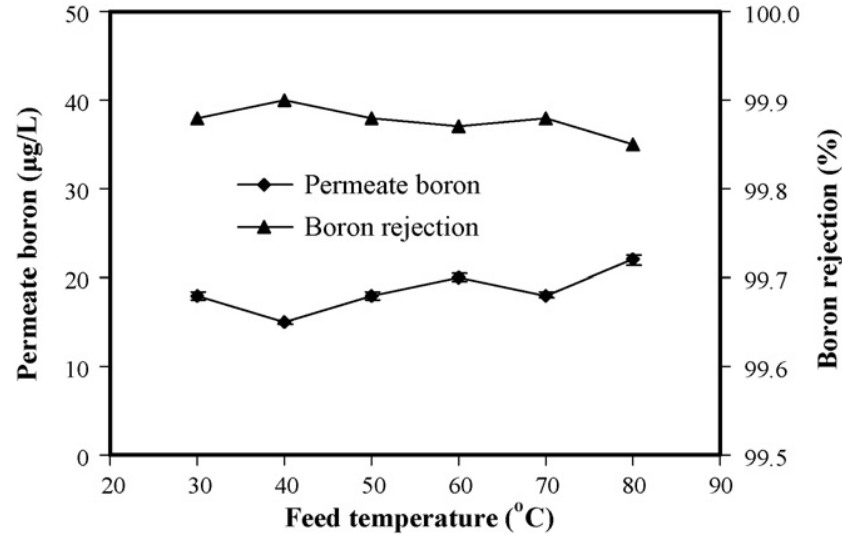

Fig. 5. Variation of permeate boron as a function of the feed temperature $\left(V_{f}=60 \mathrm{~L} / \mathrm{h}\right.$, $V_{p}=65 \mathrm{~L} / \mathrm{h}, T_{p}=20^{\circ} \mathrm{C}, C_{f}=15 \mathrm{mg} / \mathrm{L}$, at natural $\left.\mathrm{pH} 6.5-8.5\right)$.

tration was less than $22 \pm 0.55 \mu \mathrm{g} / \mathrm{L}$ at all feed temperatures and all the boron rejection efficiency could be over $99.8 \%$. All the experiment results indicated that the PVDF membrane possessed good property of heat-resistance and it could retain hydrophobic under different feed temperature conditions.

\subsection{Effect of feed salt concentration}

To investigate the effect of feed salt concentration on boron rejection, a series of boron removal experiments were carried out in the presence of $\mathrm{NaCl}, \mathrm{CaCl}_{2}$ and $\mathrm{Na}_{2} \mathrm{SO}_{4}$, respectively. The feed temperature was fixed at $50^{\circ} \mathrm{C}$ and the boron concentration of feed was $15 \mathrm{mg} / \mathrm{L}$.

It can be noted from Fig. 6 that feed salt concentration had no marked influence on boron rejection. For these three kinds of salts, the permeate boron concentration was below $26 \pm 0.50 \mu \mathrm{g} / \mathrm{L}$ and all the boron rejection efficiency could be over $99.8 \%$. Besides, the permeate conductivity kept less than $3.0 \mu \mathrm{S} / \mathrm{cm}$ during the whole process, which was not illustrated in the figure. All of these results demonstrated that the membrane had no selective rejection of nonvolatile solute. The permeate flux kept stable at about $10.5 \mathrm{~kg} / \mathrm{m}^{2} \mathrm{~h}$ and was hardly affected by feed salt concentration in the studied range. This finding is in agreement with the result previously reported by Alklaibi and Lior [46]. According to the Raoult's law, the saturated vapor partial pressure difference $(\Delta P)$ between pure water and dilute salt solution at same temperature can be calcu-

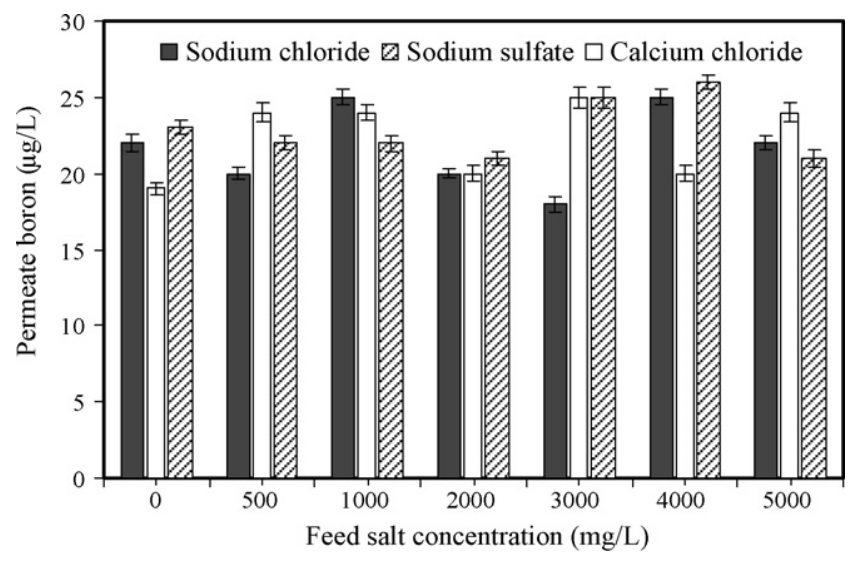

Fig. 6. The influence of feed salt concentration on the boron rejection $\left(V_{f}=60 \mathrm{~L} / \mathrm{h}\right.$ $V_{p}=65 \mathrm{~L} / \mathrm{h}, T_{f}=50^{\circ} \mathrm{C}, T_{p}=20^{\circ} \mathrm{C}$, feed boron concentration $=15 \mathrm{mg} / \mathrm{L}$, at natural $\mathrm{pH}$ 6.5-8.5). 


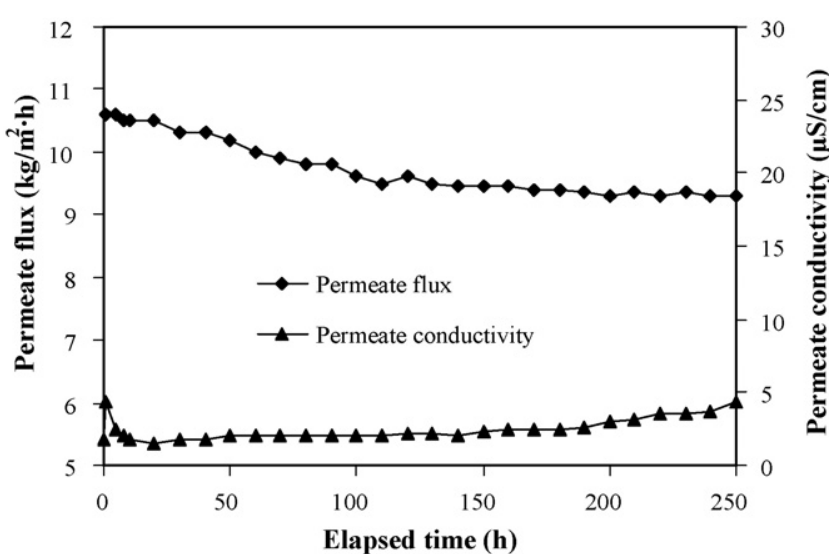

Fig. 7. Variation of permeate flux and permeate conductivity during continuous $250 \mathrm{~h}$ DCMD process for boron removal from natural groundwater sample $\left(V_{f}=60 \mathrm{~L} / \mathrm{h}, V_{p}=65 \mathrm{~L} / \mathrm{h}, T_{f}=50^{\circ} \mathrm{C}, T_{p}=20^{\circ} \mathrm{C}\right.$, initial $\mathrm{pH}$ of feed water 7.7 , without any acid addition).

lated as follows:

$\Delta P=P_{o} \frac{m}{55.5}$

where $P_{o}$ is the saturated vapor pressure of pure water $(\mathrm{Pa}), m$ is the molar concentration of solute in dilute salt solution $(\mathrm{mol} / \mathrm{L})$. From Eq. (3), it can be seen that the salt concentration has no significant influence on the saturated vapor partial pressure in the given concentration range, this explaining the permeate flux had no remarkable change with the concentration increasing.

\subsection{Natural groundwater application}

The natural groundwater sample containing $12.7 \mathrm{mg} / \mathrm{L}$ of boron was treated by DCMD process with the feed temperature at $50^{\circ} \mathrm{C}$. The experiment results shown in Fig. 7 demonstrate that the direct application of the natural groundwater as feed for DCMD process resulted in a rapid decline of the permeate flux.

All of these results were mainly due to the formation of deposits. Heating the feed caused a shift from bicarbonate ion to the carbonate ion and scale deposits were formed from those salts whose solubility was generally limited. These scale deposits scattered on the membrane surface would cause pores clogging and pollute the membrane. Therefore, the permeate flux was decreased with the prolongation of operating time. Although the scale deposits polluted the membrane, the quality of obtained permeate was maintained. During the whole process, the permeate conductivity kept below $5.0 \mu \mathrm{S} / \mathrm{cm}$ and the permeate boron concentration was less than $20 \pm 0.52 \mu \mathrm{g} / \mathrm{L}$ (Fig. 8). The SEM image of the deposits scattered on the membrane surface is shown in Fig. 9. The SEM-EDS analysis revealed that the deposit consisted chiefly of $\mathrm{Ca}(45.8 \mathrm{wt} \%)$, $\mathrm{O}$ (40.3 wt\%), C (11.6 wt\%) and $\mathrm{Cl}$ (1.7 wt\%), which meant that the deposit was mainly composed of $\mathrm{CaCO}_{3}$.

In order to eliminate the negative influence of scale deposits formation during the DCMD process, further studies of the DCMD process were carried out at the initial feed $\mathrm{pH} 4.0$ adjusted by addition of $0.1 \mathrm{~mol} / \mathrm{L} \mathrm{HCl}$ to the feed. The experimental result is shown in Figs. 10 and 11. As can be seen, the acidification of the feed enhances the stability of the process in a significant degree. There was no obvious decline of permeate flux during the $250 \mathrm{~h}$ continuous operation process. The permeate conductivity stabilized at about $2.5 \mu \mathrm{S} / \mathrm{cm}$ and the permeate boron concentration was in the range of $15 \pm 0.36$ to $18 \pm 0.40 \mu \mathrm{g} / \mathrm{L}$. Besides, the $\mathrm{pH}$ of permeate remained between 7.2 and 7.6 during the whole process, which indicated that pre-acidification had no significant influence on the permeate $\mathrm{pH}$. All of the results demonstrated that pre-acidification

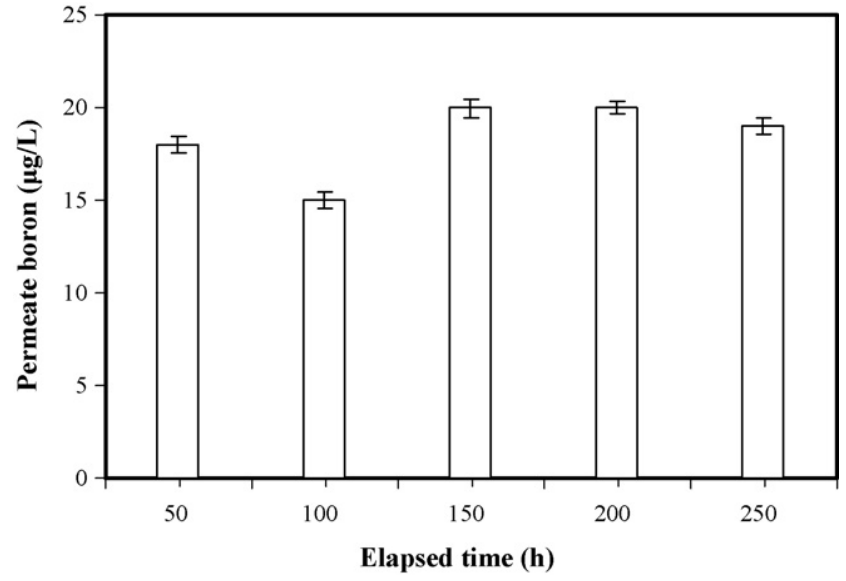

Fig. 8. Variation of permeate boron during continuous $250 \mathrm{~h}$ DCMD process for boron removal from natural groundwater sample $\left(V_{f}=60 \mathrm{~L} / \mathrm{h}, V_{p}=65 \mathrm{~L} / \mathrm{h}, T_{f}=50^{\circ} \mathrm{C}\right.$, $T_{p}=20^{\circ} \mathrm{C}$, initial $\mathrm{pH}$ of feed water 7.7 , without any acid addition).

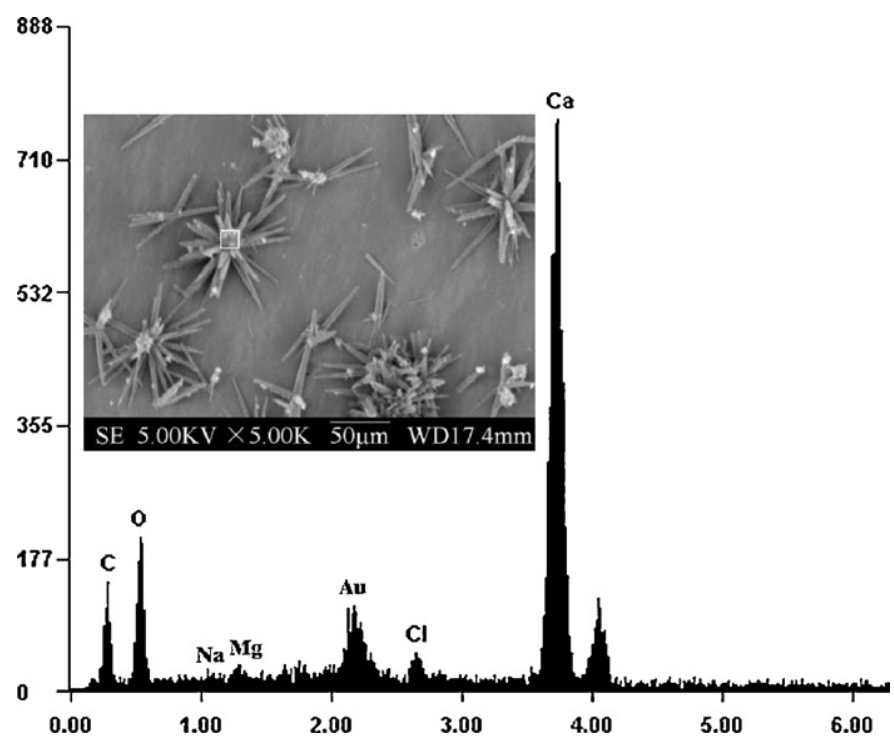

Fig. 9. SEM image and microanalysis report of the deposits scattered on the membrane surface.

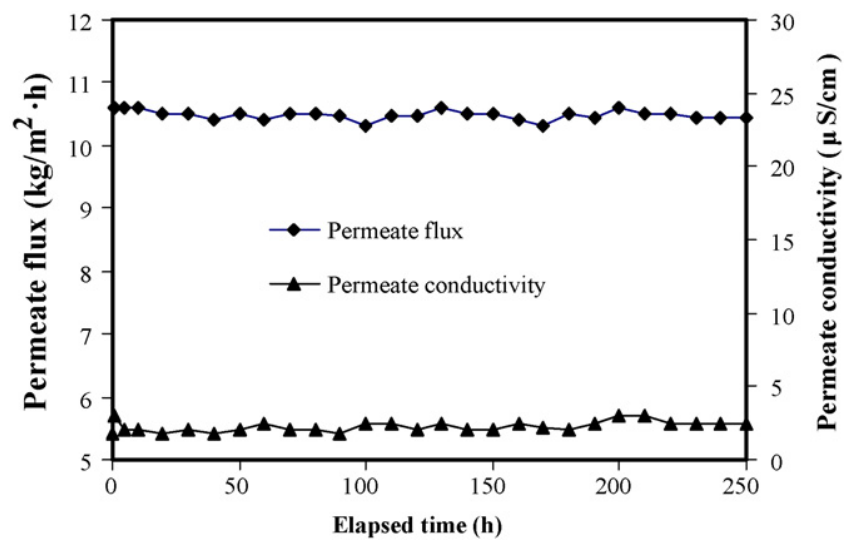

Fig. 10. Variation of permeate flux and permeate conductivity during continuous $250 \mathrm{~h}$ DCMD process for boron removal from natural groundwater sample $\left(V_{f}=60 \mathrm{~L} / \mathrm{h}, V_{p}=65 \mathrm{~L} / \mathrm{h}, T_{f}=50^{\circ} \mathrm{C}, T_{p}=20^{\circ} \mathrm{C}\right.$, initial pH of feed water 4.0 , with $0.1 \mathrm{~mol} / \mathrm{L}$ $\mathrm{HCl}$ addition). 


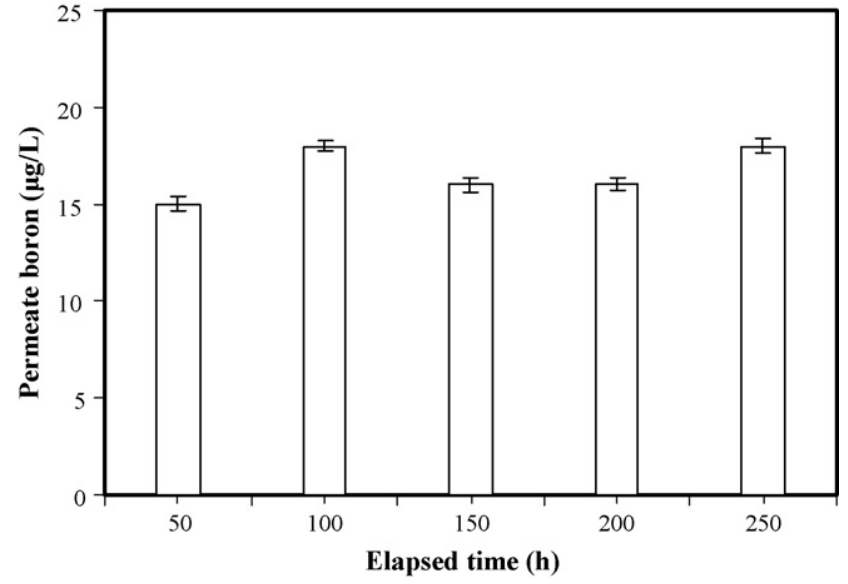

Fig. 11. Variation of permeate boron during continuous $250 \mathrm{~h}$ DCMD process for boron removal from natural groundwater sample $\left(V_{f}=60 \mathrm{~L} / \mathrm{h}, V_{p}=65 \mathrm{~L} / \mathrm{h}, T_{f}=50^{\circ} \mathrm{C}\right.$, $T_{p}=20^{\circ} \mathrm{C}$, initial $\mathrm{pH}$ of feed water 4.0 , with $0.1 \mathrm{~mol} / \mathrm{L} \mathrm{HCl}$ addition). was an efficient method to eliminate the negative effects of scale deposits and the PVDF membrane had stable permeability and hydrophobicity.

The SEM images of the hydrophobic PVDF membranes taken before and after $250 \mathrm{~h}$ continuous boron removal from pre-acidified groundwater are shown in Fig. 12. It can be seen from these micrographs that there were no marked changes in the inner surface and cross-section including the finger-like cavity and sponge-like sublayer. This finding is different from the result previously reported by Barbe et al. [47], who found that the surface of polypropylene (PP) membrane changed after $72 \mathrm{~h}$ water contact experiment. An increase in the values of various morphology parameters such as pore area, pore length, pore breadth, and pore diameter was observed. The different results may be attributed to the difference of materials used for membrane preparation. It was well known that PVDF possessed better properties such as chemical-resistance, heat-resistance and hydrophobicity compared with PP.
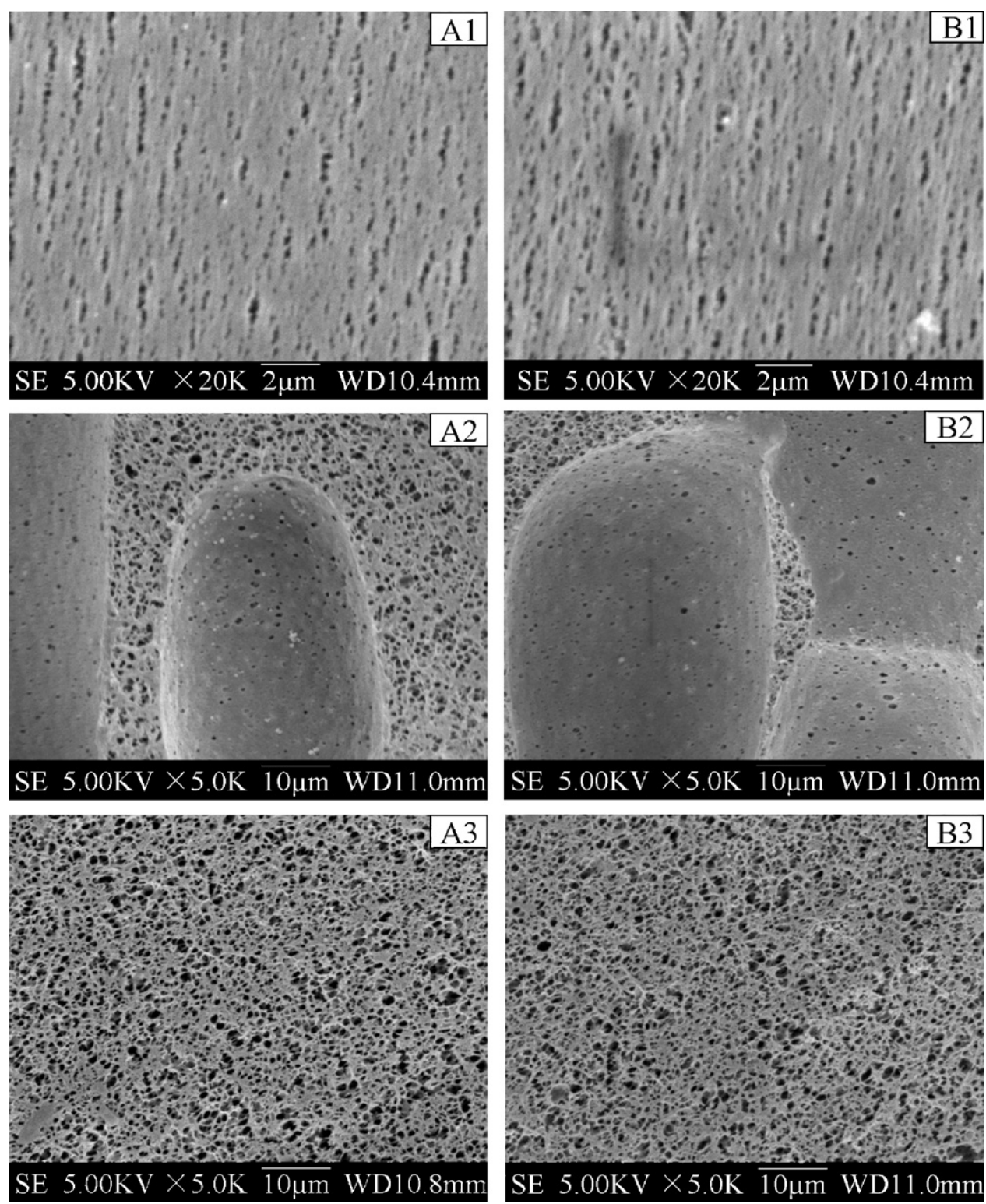

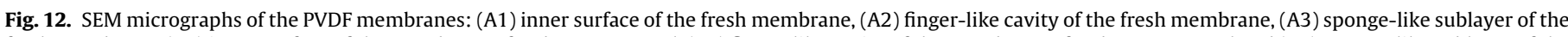

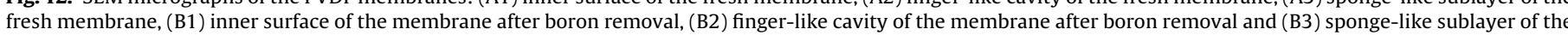
membrane after boron removal. 


\section{Conclusions}

In the present work, the application of DCMD for boron removal from aqueous solution was investigated systematically and the following conclusions were obtained:

(1) All the boron rejections were above $99.8 \%$ in the feed $\mathrm{pH}$ range of 3.0-11.0 and the boron rejection was less dependent on the feed $\mathrm{pH}$, which was greatly different from RO process.

(2) The feed boron concentration had no significant effect on the boron rejection and the permeate boron kept below the maximum permissible level even when the feed boron concentration increased to $750 \mathrm{mg} / \mathrm{L}$.

(3) The permeate flux was enhanced exponentially without sacrificing the boron rejection efficiency with the feed temperature increasing and boron removal was greater than $99.8 \%$ at all the temperatures tested.

(4) The feed salt concentration had no marked influence on the boron rejection and the permeate flux kept stable with the feed salt concentration increasing to some extent.

(5) The natural groundwater sample containing $12.7 \mathrm{mg} / \mathrm{L}$ of boron was treated by DCMD process. The permeate boron kept below $20 \mu \mathrm{g} / \mathrm{L}$ whether the feed was acidified or not, but pre-acidification was helpful to maintain the permeate flux stability.

\section{Acknowledgments}

This work was supported by the National High Technology Research and Development Program of China (Grant no. 2009AA063901), the National Natural Science Foundation of China (Grant no. 20907066) and the special fund from the State Key Laboratory of Environmental Aquatic Chemistry (Project \# 08Y09ESPCR).

\section{References}

[1] I. Yilmaz Ipek, R. Holdich, N. Kabay, M. Bryjak, M. Yuksel, Kinetic behaviour of boron selective resins for boron removal using seeded microfiltration system, React. Funct. Polym. 67 (2007) 1628-1634.

[2] O.P. Ferreira, S.G. Moraes, N. Durán, L. Cornejo, O.L. Alves, Evaluation of boron removal from water by hydrotalcite-like compounds, Chemosphere 62 (2006) 80-88.

[3] E. Huertas, M. Herzberg, G. Oron, M. Elimelech, Influence of biofouling on boron removal by nanofiltration and reverse osmosis membranes, J. Membr. Sci. 318 (2008) 264-270.

[4] L. Melnyk, V. Goncharuk, I. Butnyk, E. Tsapiuk, Boron removal from natural and wastewaters using combined sorption/membrane process, Desalination 185 (2005) 147-157.

[5] G.W. Sofw, Influence of boron to the organism communities of the system sewage treatment plant-receiving waters (model investigations), J. Eng. Vers.: Int. Trade J. 126 (2000) 17-24.

[6] E.M. Shwarts, Are boron compounds useful or harmful? J. Chem. Interest Stable Progr. 2 (1994) 501-505.

[7] A.T. Philipenko, V.D. Grebenyk, L.A. Melnik, Extraction of boron compounds from natural and industrial waters, Khim. Tekhnol. Vody. 12 (1990) 195-210.

[8] World Health Organization, Boron, Environmental Health Criteria Monograph 204, WHO, IPCS, Geneva, 1998.

[9] D. Kavak, Removal of boron from aqueous solutions by batch adsorption on calcined alunite using experimental design, J. Hazard. Mater. 163 (2009) 308314.

[10] Z.C. Çelik, B.Z. Cana, M.M. Kocakerim, Boron removal from aqueous solutions by activated carbon impregnated with salicylic acid, J. Hazard. Mater. 152 (2008) 415-422.

[11] M.M.F. García-Soto, E.M. Camachob, Boron removal by means of adsorption with magnesium oxide, Sep. Purif. Technol. 48 (2006) 36-44.

[12] N. Öztürk, D. Kavak, Boron removal from aqueous solutions by batch adsorption onto cerium oxide using full factorial design, Desalination 223 (2008) 106-112.

[13] Y. Seki, S. Seyhan, M. Yurdakoç, Removal of boron from aqueous solution by adsorption on $\mathrm{Al}_{2} \mathrm{O}_{3}$ based materials using full factorial design, J. Hazard. Mater. 138 (2006) 60-66.

[14] N. Öztürk, D. Kavak, Adsorption of boron from aqueous solutions using fly ash: batch and column studies, J. Hazard. Mater. 127 (2005) 81-88.
[15] Y. Cengeloglu, A. Tor, G. Arslan, M. Ersoz, S. Gezgin, Removal of boron from aqueous solution by using neutralized red mud, J. Hazard. Mater. 142 (2007) 412-417.

[16] S. Karahan, M. Yurdakoç, Y. Seki, K. Yurdakoç, Removal of boron from aqueous solution by clays and modified clays, J. Colloid Interface Sci. 293 (2006) 36-42.

[17] M.O. Simonnot, C. Castel, M. Nicolaï, C. Rosin, M. Sardin, H. Jauffret, Boron removal from drinking water with a boron selective resin: is the treatment really selective? Water Res. 34 (2000) 109-116.

[18] T.E. Köse, N. Öztürk, Boron removal from aqueous solutions by ion-exchange resin: column sorption-elution studies, J. Hazard. Mater. 152 (2008) 744-749.

[19] N. Kabay, I. Yılmaz, S. Yamac, S. Samatya, M. Yuksel, U. Yuksel, M. Arda, M. Sağlam, T. Iwanaga, K. Hirowatari, Removal and recovery of boron from geothermal wastewater by selective ion exchange resins. I. Laboratory tests, React. Funct. Polym. 60 (2004) 163-170.

[20] N. Kabay, I. Yılmaz, S. Yamac, M. Yuksel, U. Yuksel, N. Yildirim, O. Aydogdu, T. Iwanaga, K. Hirowatari, Removal and recovery of boron from geothermal wastewater by selective ion-exchange resins. II. Field tests, Desalination 167 (2004) 427-438.

[21] N. Kabay, S. Sarp, M. Yuksel, M. Kitis, H. Koseoğlu, Ö. Arar, M. Bryjak, R. Semiat, Removal of boron from SWRO permeate by boron selective ion exchange resins containing $N$-methyl glucamine groups, Desalination 223 (2008) 49-56.

[22] N. Kabay, İ. Yılmaz, M. Bryjak, N. Kabay, İ. Yilmaz, M. Bryjak, M. Yüksel, Removal of boron from aqueous solutions by a hybrid ion exchange-membrane process, Desalination 198 (2006) 158-165.

[23] N. Kabay, S. Sarp, M. Yuksel, Ö. Arar, M. Bryjak, Removal of boron from seawater by selective ion exchange resins, React. Funct. Polym. 67 (2007) 1643-1650.

[24] R. Boncukcuoğlu, A.E. Yılmaz, M.M. Kocakerimb, M. Çopur, An empirical model for kinetics of boron removal from boron containing waste waters by ion exchange in a batch reactor, Desalination 160 (2004) 159-166.

[25] U. Schilde, E. Uhlemann, Extraction of boric acid from brines by ion exchange, Int. J. Miner. Process. 32 (1991) 295-309.

[26] C. Jacob, Seawater desalination: boron removal by ion exchange technology, Desalination 205 (2007) 47-52.

[27] A. Bick, G. Oron, Post-treatment design of seawater reverse osmosis plants: boron removal technology selection for potable water production and environmental control, Desalination 178 (2005) 233-246.

[28] N. Öztürk, D. Kavak, T.E. Köse, Boron removal from aqueous solution by reverse osmosis, Desalination 223 (2008) 1-9.

[29] Y. Cengeloglu, G. Arslan, A. Tor, I. Kocak, N. Dursun, Removal of boron from water by using reverse osmosis, Sep. Purif. Technol. 64 (2008) 141-146.

[30] M. Turek, B. Bandura, P. Dydo, Electrodialytic boron removal from SWRO permeate, Desalination 223 (2008) 17-22.

[31] Z. Yazicigil, Y. Oztekin, Boron removal by electrodialysis with anion-exchange membranes, Desalination 190 (2006) 71-78.

[32] M. Faigon, D. Hefer, Boron rejection in SWRO at high pH conditions versus cascade design, Desalination 223 (2008) 10-16.

[33] L. Melnik, O. Vysotskaja, B. Kornilovich, Boron behavior during desalination of sea and underground water by electrodialysis, Desalination 124 (1999) 125-130.

[34] P. Dydo, M. Turek, J. Ciba, J. Trojanowska, J. Kluczka, Boron removal from landfill leachate by means of nanofiltration and reverse osmosis, Desalination 185 (2005) 131-137.

[35] M.S. El-Bourawi, Z. Ding, R. Ma, M. Khayet, A framework for better understanding membrane distillation separation process, J. Membr. Sci. 285 (2006) 4-29.

[36] K.W. Lawson, D.R. Lloyd, Membrane distillation, J. Membr. Sci. 124(1997) 1-25.

[37] E. El-Zanati, K.M. El-Khatib, Integrated membrane-based desalination system, Desalination 205 (2007) 15-25.

[38] J.H. Hanemaaijer, J.V. Medevoort, A.E. Jansen, C. Dotremont, E.V. Sonsbeek, T. Yuan, L.D. Ryck, Memstill membrane distillation-a future desalination technology, Desalination 199 (2006) 175-176.

[39] L. Martínez-Díez, F.J. Florido-Díaz, Desalination of brines by membrane distillation, Desalination 137 (2001) 267-273.

[40] M.S.H. Bader, A hybrid liquid-phase precipitation (LPP) process in conjunction with membrane distillation (MD) for the treatment of the INEEL sodiumbearing liquid waste, J. Hazard. Mater. 121 (2005) 89-108.

[41] K. Bélafi-Bakó, B. Koroknai, Enhanced water flux in fruit juice concentration: coupled operation of osmotic evaporation and membrane distillation, J. Membr. Sci. 269 (2006) 187-193.

[42] M. Tomaszewska, Concentration and purification of fluosilicic acid by membrane distillation, Ind. Eng. Chem. Res. 39 (2000) 3038-3041.

[43] M. Gryta, K. Karakulski, The application of membrane distillation for the concentration of oil-water emulsions, Desalination 121 (1999) 23-29.

[44] T.G. Zakrzewska, M. Harasimowicz, A.G. Chmielewski, Membrane processes in nuclear technology - application for liquid radioactive waste treatment, Sep. Purif. Technol. 22 (2001) 617-625.

[45] Y.B. Yun, R.Y. Ma, W.Z. Zhang, A.G. Fane, J.D. Li, Direct contact membrane distillation mechanism for high concentration $\mathrm{NaCl}$ solutions, Desalination 188 (2006) 251-262.

[46] A.M. Alklaibi, N. Lior, Heat and mass transfer resistance analysis of membrane distillation, J. Membr. Sci. 282 (2006) 362-369.

[47] A.M. Barbe, P.A. Hogan, R.A. Johnson, Surface morphology changes during initial usage of hydrophobic, microporous polypropylene membranes, J. Membr. Sci. 172 (2000) 149-156. 